\title{
Design and Development of Linear Algebra Peer Tutoring Strategy to Develop Students Mathematical Thinking Processes Based on Experts' Evaluation
}

\author{
Muhammad Sani Abdurrahman ${ }^{1, *}$, Abdul Halim Abdullah ${ }^{2}$, Sharifah Osman ${ }^{2}$ \\ ${ }^{1}$ Department of Mathematics, Waziri Umaru Federal Polytechnic, Kebbi State, Nigeria \\ ${ }^{2}$ Faculty of Social Sciences and Humanities, Universiti Teknologi Malaysia (UTM), Malaysia
}

Received May 9, 2020 ; Revised June 10, 2020; Accepted June 15, 2020

Copyright $\mathrm{O} 2020$ by authors, all rights reserved. Authors agree that this article remains permanently open access under the terms of the Creative Commons Attribution License 4.0 International License

\begin{abstract}
This study aims at designing, developing and evaluating the effectiveness of a learning strategy known as linear algebra peer tutoring strategy (LAPTS) in a polytechnic classroom setting in order to develop students mathematical thinking processes (MTPs) based on Mason's approach. Preliminary investigations were conducted on the conventional teaching and learning in order to identify students' problems in linear algebra (LA) and its outcomes were then analyze to fit the theoretical framework as well as meet the need for the design. LAPTS was designed using ADDIE (analysis, design, development, implementation, evaluation) model employing both quantitative and qualitative methods. During the formative evaluation, a pilot study was conducted to verify and validate the LAPTS through experts' content validity and interviews. Seventy-three students (36 students for experimental group and 37 students for control group) voluntarily participated in the study to ascertain the effectiveness of the LAPTS based on their MTPs. The findings show a significant difference between the mean scores of both experimental and control groups on posttest at $\alpha=0.05$ ( $p=0.000)$ level of significant. In addition, the analysis of the students' MTPs showed a significant difference with respect to specializing, generalizing and conjecturing with a non-significant difference in convincing. Results from the study showed development of MTPs and learning among the students. The findings in this research indicated that, LAPTS has the potential to develop students' MTPs with respect to Mason's approach and learning in LA.
\end{abstract}

Keywords Mathematical Thinking Process, Linear Algebra, Peer Tutoring Strategy, ADDIE Model, Experts' Evaluation

\section{Introduction}

The challenges of teaching in the $21^{\text {st }}$ century are to create opportunities to students and developed their own thinking skills in order to learn more concepts in many educational fields as well as make them think independently in order to make use of their learned experiences. Students nowadays are challenged to think critically on their own, use available resources at their disposal so as to understand more ideas and develop skills in many academic areas. Helping students to learn how to think mathematically has been regarded as an important educational goal, as it is used to describe thought that is purposeful, reasoned, and goal directed [1]. He emphasized that a greater role in the mathematical thinking skills of students is mostly played by teachers because the ability of students to think mathematically can be directly affected by the teachers' approaches to teaching and learning. This means that applying students centered learning approaches will definitely make the teaching to be effective through developing and enhancing students' performance in the classroom.

Mathematical thinking is a dynamic process that allow students to make their thoughts more in-depth through handling and expanding their understanding [2]. Mathematical thinking is viewed by many researchers as a process of extending the complexities of students' ideas which combines several mental activities of "exemplifying, specializing, completing, deleting, correcting, comparing, sorting, organizing, changing, varying, reversing, altering, generalizing, conjecturing, explaining, justifying, verifying, convincing, and refuting". Ref [3] posited that different viewpoints showed that mathematical thinking is among the main goal of mathematics education, which plays a significant role in the teaching and learning of mathematics so as to tackle the problems of students. However, mathematical thinking is described by [4] as the ability to apply problem solving strategies, metacognitive processes, beliefs and effects, and practices which does not merely involve the mathematics content knowledge alone.

Linear algebra is among the branches of mathematics which forms the foundation of modern algebra. It plays an 
important historical role in the development of many mathematical structures such as rings and vector spaces. Linear algebra is among the unavoidable advanced mathematics courses that many students encounter at higher institution levels; therefore, promoting mathematical thinking in it could be among the most important thing in supporting and improving students learning. A study conducted by $[5,6]$ showed that mathematical thinking is among the core of the major theories of linear algebra as it carries the main burden in all of the scientific and technological reasoning. So in terms of teaching and learning of mathematical thinking, education design now demands teaching strategies that emphasize the participation of students in their learning, focusing on knowledge construction [7-9]. Therefore, to develop students' mathematical thinking skills in linear algebra, the teaching and learning should be encourage with a constructive way of finding solution to problems rather than over dependence on the usual traditional approach which sometimes lead to learning through memorization without understanding. Hence, for students to be able to develop their mathematical thinking skills, they need to establish, justify and broaden their views, ideas and beliefs in order to be active participants instead of being passive knowledge consumers, which makes them accountable for their own thought and learning.

In a linear algebra classroom, peer tutoring strategy can be seen as a situation where students teach their fellow students linear algebra concepts with the help of a teacher who act as a facilitator. Peer tutoring can as well help students in developing their mathematical thinking in linear algebra classroom as it served as an instructional strategy whereby small learning groups are assigned to work together on a common algebraic activity that allows them to act as tutors and tutors [10-12]. Consequently, students' mathematical thinking in linear algebra can also be improved if teachers assume the role of facilitators where by the students are trained to be responsible of their own understanding of each of the concept learned which makes the activity to be learner-centred, democratic and interactive. Effective mathematical thinking can be developed through collaborative work among pairs and groups if there exist a shift in sharing of ideas most especially when it comes to problems that involves abstract thinking $[13,14]$. Additionally the study conducted by [15] identified some terminologies to be used in developing students' thinking skills in an algebraic classroom and any other classroom which include: posing questions, experimenting with ideas, taking risks, playing around and working collaboratively. Ref [16] suggested that well-adjusted mathematical programs such as conceptual learning, skills development and maintenance, as well as learning to confront problems should be conducted so that students can enhance their mathematical thinking skills. He further stresses that mathematical thinking can be develop most effectively by students through applying the learned concepts and skills in more passionate and practical ways.
The rationale behind selecting peer tutoring as an instructional strategy in this study is that different research works have reported that peer tutoring in college mathematics have great impact on the development of intellectual and moral values of students. Accordingly, the language used among peers often helps them to cooperate and work as a team in such a way that all members can; freely express their ideas, master different concepts, be responsible, and be resourceful as well.

\section{Statement of the Problem}

According to [17], mathematical thinking has been adopted in Nigerian institutions as one of the nation's educational goal to make students creative but has not been fully incorporated and also recorded low achievement in the school curriculum implementation. The students' ability to think mathematically and use it in solving linear algebra problems is among the ultimate goal of teaching mathematics at higher institution level, so that students can perform mathematical work on their own and also understand the mathematics they have studied is relevant to real-world situations. Knowing how students learn increases the option of teaching strategies that are best suited to improving the mathematical thinking skills of students $[18,19]$. The challenge in teaching is to procedure experiences that will engage students and promote their mathematical thinking skills in order to enable them to explain, analyze, communicate and apply certain experiences that are necessary to make sense of what was learn from the instructor.

\section{Objectives of the Study}

The following objectives were identified in this study:

i. To determine the experts' evaluation about the linear algebra peer tutoring strategy (LAPTS) and its activities.

ii. To test the effectiveness of LAPTS learning strategy on students' mathematical thinking processes.

\section{Theoretical Framework}

The theoretical framework for this study incorporated the Vygotsky's scaffolding technique and Mason's mathematical thinking approach in an attempt to develop polytechnic students' mathematical thinking in linear algebra. This framework will provide a lens in viewing how peer scaffolding technique will lead to the development and improvement of students' mathematical thinking understanding in linear algebra as shown in Figure 1 : 


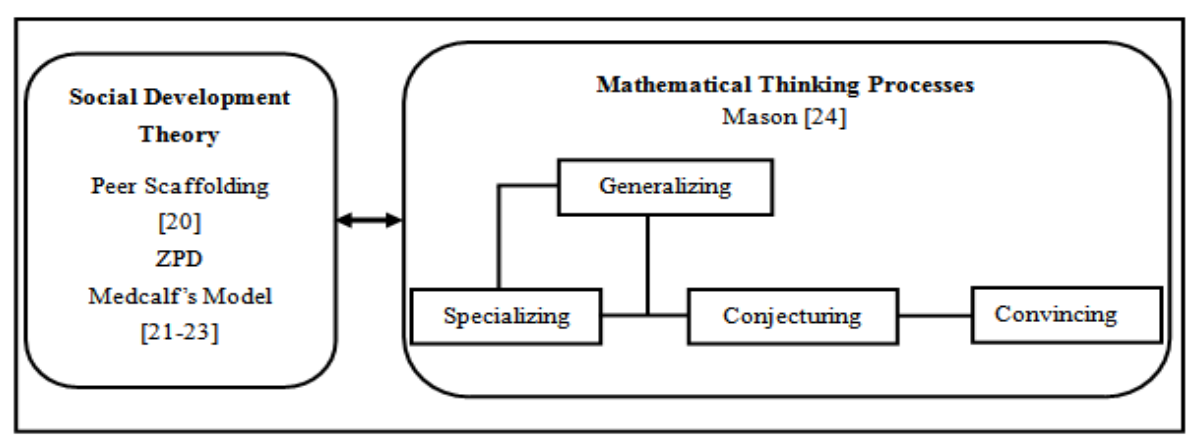

Figure 1. The Proposed Theoretical Framework

Vygotsky believed that socio-cultural factors were essential to cognitive development; seeing all learning as social in origin and that social interactions potentially lead to mental functions development [25]. Vygotsky's ZPD can give a theoretical model for understanding how students developed as mathematical thinkers and can as well give teachers ways to think about facilitating student development through modeling what they want the students to do so that student will clearly understand and perform better in the given tasks [26, 27]. For any teacher to be able to guide his/her instruction in Vygotsky's theory, [28] pointed out that the teacher should be interested in the scaffolding of the students; more knowledgeable peer provides assistance to others in order to make them complete a given task. Vygotsky also believed that peer collaboration encourages learners to assist one another and discussed their ideas and opinions freely which is considered as a powerful tool for developing a more reflective learning and at the same time enhances students learning. Thus, a research conducted by [29-31] suggested that Vygotsky's ZPD theory can improve students' thinking ability and also makes learning more meaningful, easier, manageable, effective and efficient.

\section{Design and Development of the Linear Algebra Peer Tutoring Strategy (LAPTS)}

The learner's requirement is one of the priority element in the design and development of an effective classroom instruction [32]. Development of classroom instruction involves a systematic process by which lesson materials are designed, developed, and implemented [33]; as well as provide a set of guidelines or strategies (which are based on learning theories and practices) that are created to describe how the classroom instruction process might be carried out in different settings $[34,35]$. The model used in the development of the classroom learning instruction (LAPTS) in this study is ADDIE model. ADDIE model was first developed in 1975 by Florida State University in collaboration with the Department of Defense for military purposes as an instructional design [30]. The ADDIE model organizes Gagne's nine instructional steps into five high-level phases (Analysis, Design, Development, Implementation, Evaluation) to direct instructional designers as they approach classroom instruction practice [36,37]. The ADDIE model has a sequence of five phases which are to be followed in logical order so that the output of each phase provides the input for the next phase [38]. According to [39], each phase of the process is informed by rapid prototyping where feedback from students, instructors, and other targeted users informs the next phase. Figure 2 below shows the five phases of ADDIE model which was used in developing the classroom instruction of this study.

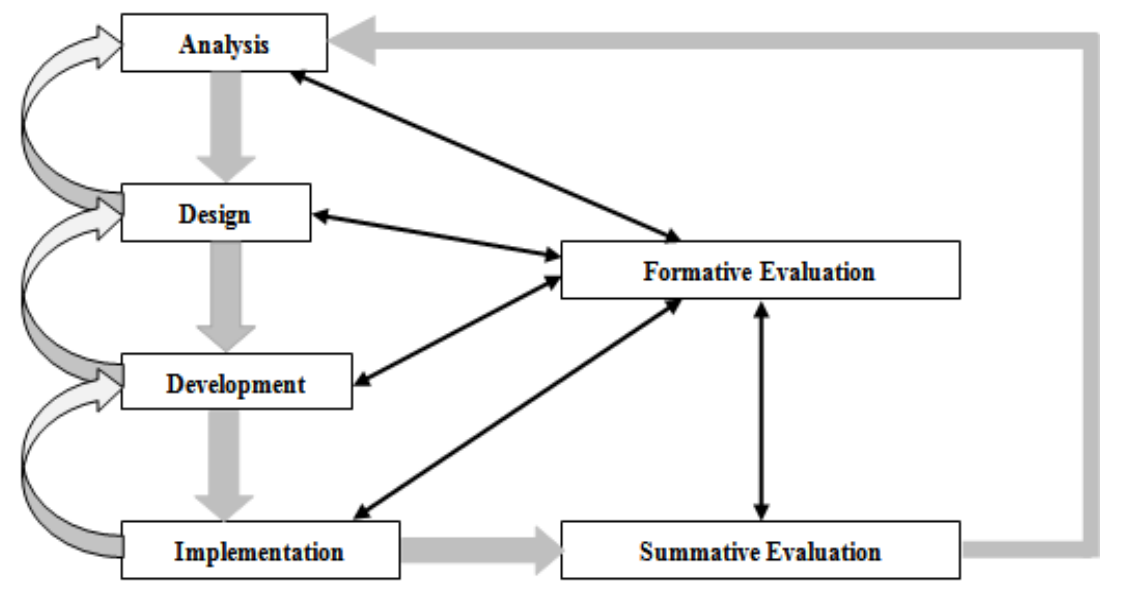

Figure 2. ADDIE Model 
The ADDIE model fits the needs of the researchers as it explicitly breaks down the process of designing and developing of the learning strategy into five different stages (Analysis, Design, Development, Implementation, and Evaluation) as well as makes emphases on continuous evaluation (formative) throughout the first four phases, i.e. from analysis to implementation. The formative evaluation results of each process will direct the instructional designer back to any earlier stage, whereas the end result of one stage will become the starting point for the next stage. Similarly, after the final version of instruction is implemented, the researchers can review and amend the linear algebra peer tutoring strategy (summative evaluation) until it reaches the predetermined objectives. This means that reviews and evaluations often occur after each step in such a way that the researchers were able to catch up some certain errors or explain misunderstanding before moving on to the next step in the process. The components of any classroom instruction via ADDIE model include needs assessment, identifying of learning objective in order to meet the learners' needs, designing and selecting appropriate instructional strategy, development and implementation of the instructional design, as well as evaluating the instruction and learners' outcomes. Figure 3 illustrated the general flowchart of the design and development of the linear algebra peer tutoring strategy (LAPTS):

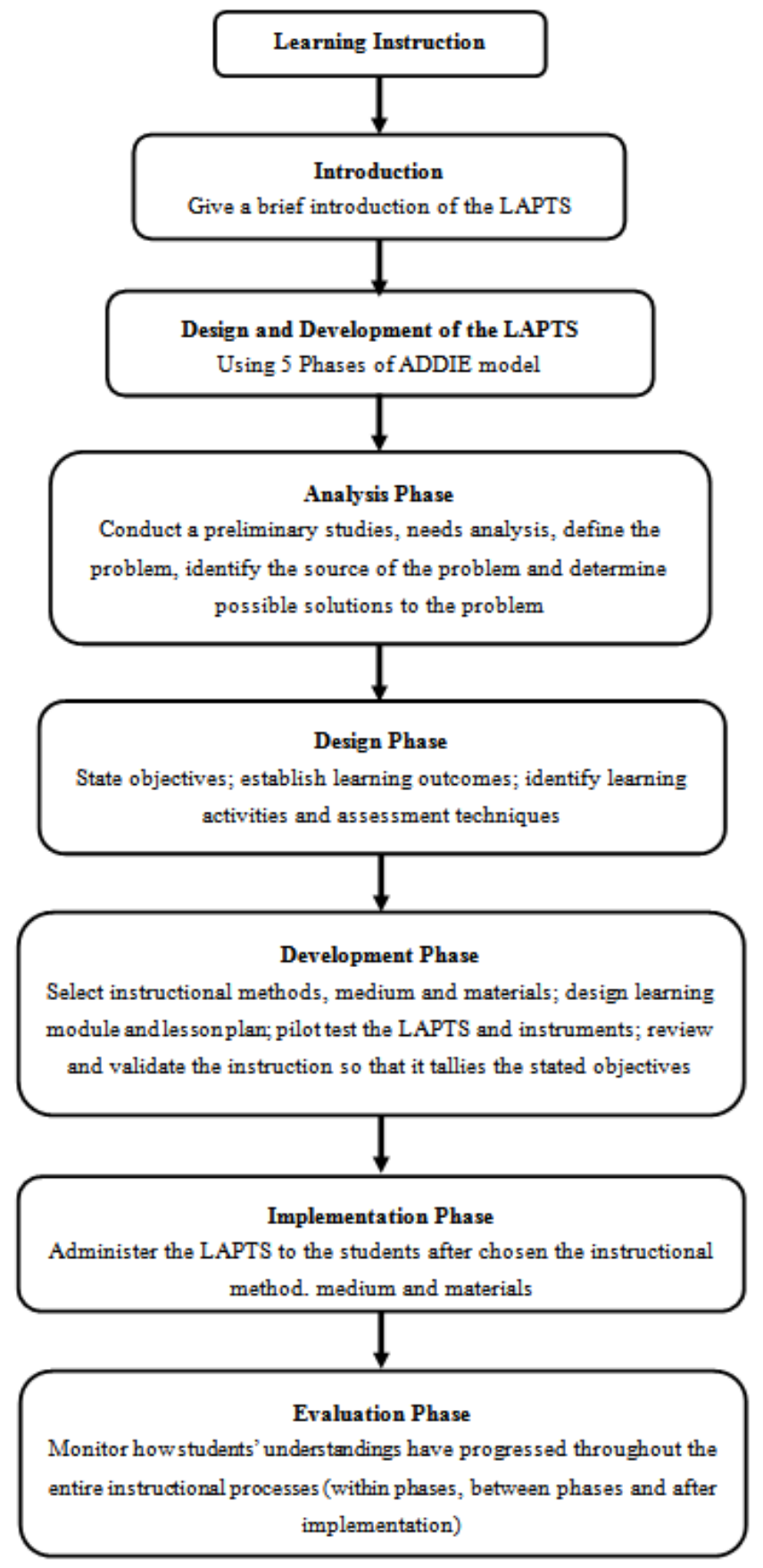

Figure 3. General Flowchart of the Linear Algebra Peer Tutoring Strategy (LAPTS) 


\subsection{Analysis Phase}

The organizational plan of this model in this research start out in the analysis stage, as it is the most important part and the foundation for all other phases in ADDIE model. The researchers examined the need to incorporate peer tutoring strategy in a linear algebra classroom to develop polytechnic students' mathematical thinking processes. Based on the activities performed in the preliminary study, it is evident that there is the need for a learning strategy that will allow students to work collaboratively in order to improve their mathematical thinking processes as the conventional learning was identify to have some challenges in achieving this objective. This becomes the basis for the justification of the design and development of the LAPTS. With the confirmation of this need, the researchers then reflected on whether there proposed learning strategy would fit this need. This reflection led to the inputs for the next phase (i.e. design phase).

\subsection{Design Phase}

The second phase of the ADDIE model is the design phase which involved the use of the analysis phase results to formulate a strategy for the development of the instruction. In order to be successful in this phase, the researchers decided on the materials, lessons and topics to be covered, the various objectives to be accomplished when the program is in place, as well as how to achieve these objectives. This means that the learning objectives and the objectives of the instructional design has to be stated in writing statements so as to describe what students will do as a result of the instruction. A system plan was designed by the researchers in order to meet the learners' requirements through the determination of the topics to be covered and the time that will be spent on each, creating lesson plan, identify learning activities and exercises, as well as identify assessment instruments and media. The researchers designed the LAPTS based on the predetermined learning outcome from the problem identification and needs analysis in order to align it with the learning outcome that will enhance learners' mathematical thinking processes in a collaborative activity. The outputs of this phase leads to the inputs for the next phase (i.e. development phase).

\subsection{Development Phase}

After the researchers reflected on their design features discussed in phase two of ADDIE model, they were ready to put it into action which become the third stage in the process (it heavily depends on the previous phases i.e. analysis and design). The researchers use a systematic design procedures in designing and developing of the classroom instruction which makes it more effective, efficient, appealing, significant and less rigorous [34, 35].
Systematic approach encourages the setting of the design objectives, provide ways in which those objective are to be achieve, as well as focus on improving the efficiency and effectiveness of the learning instructions in different settings [40]. The purpose of developing the LAPTS instruction is to help the instructors (tutors) in ensuring that they are teaching the appropriate material in an optimal manner [41]. During this phase, the researchers gathered all the information as well as the materials needed and developed the lessons into one guide. This guide was prepared as a draft material and activities; tried out with the target audience members; revise, refine and reproduce.

\subsection{Implementation Phase}

This is the fourth phase of the ADDIE model and it involves presenting the content to the students in a meaningful way, as well as facilitation of their learning through students' engagement in the learning process. All the preparation done in the previous stages are integrated in this phase to ensure the accomplishment of the research objectives. In order to carry out this phase successfully, the following three steps were considered: training the instructors, preparing the students, and making the learning environment conducive. The LAPTS covered the polytechnic ND II linear algebra content in which the samples selected for the study were subjected to peer tutoring model design by [21-23]. This model was design to help student develop their cognitive skills through pause, prompt and praise. The model encourage peers to apply four steps while trying to solve mathematics problems which include: watch, ask, show and praise. The first step requires the tutor monitoring the tutee solving the given task while the second step is asking the tutee questions in order to assist him in overcoming his mistake in case the tutee encounter difficulty. If the tutee cannot proceed alone, then the third step is taking by showing him the next step to solve the given task or a similar example and then the tutor should encourage the tutee to independently complete a similar task. The final step is to give praise for completing the task.

Before the administration of the LAPTS instructions, the researchers and research assistant scheduled a time slots for the intervention sessions so that the sessions will not interfere with the students' normal classes during the semester. The researchers and the research assistant meet the students face-to-face at first and introduce the LAPTS as well as conducted the introductory part of the learning strategy. Mathematical thinking test 1 (pretest) was administered to the students a week later, and the scores of the pretest served as the bases for pairing the students in a group of 5-6 members [42-45] with the hope that they will help each other and function as tutors and tutees under the supervision of the research assistant so as to accomplish the given task. Topics on linear algebra were distributed randomly to every member of each group in order to make them practice and be ready to function as tutors and tutees. 
This is to ensure that they familiarized themselves with the LAPTS quickly, as they apply it throughout the intervention period. The research assistant demonstrated how the students will use the LAPTS while the students explore it and ask questions concerning its content and the conduct of the exercise. The activities in the LAPTS were designed for groups, and it was aligned with collaborative knowledge sharing. The first session was aimed at introducing and explaining the previously acquired knowledge of matrices and determinants to the students. However, during the group activities, students are expected to interact with one another and work closely for idea and knowledge sharing in order to accomplish the assign task.

During the intervention, the LAPTS contain the learning module that was presented to the students inform of instructor's lesson plan. The research assistant introduce each and every session by highlighting the purpose of the session and the scope of the lesson; the students were then ask to follow the instructor's lesson plan to perform the activities. The intervention was done under natural settings whereby the research assistant make no effort to control the activities of the students as things naturally occurred [46, 47]. The research assistant further maintain the sustainability of the LAPTS by monitoring the students' activities throughout the sessions.

\subsection{Evaluation Phase}

Evaluation is the final phase of ADDIE model which measures the effectiveness of the instruction. It gives the researchers the opportunity to monitor how students' understandings have progressed through administration of test or performance activities [48-51]. At this point, the researchers are expected to observe students' knowledge, skills, application of concepts, and a change in thinking. The evaluation phase in this research is aimed at studying and reviewing the effectiveness of a LAPTS that will develop students' mathematical thinking processes. This process is vital in such a way that it ensures whether or not the instructional material meets the designed learning outcomes of the students. According to [52], evaluation is expected to take place throughout the entire learning experience which must include formative and summative assessment strategies. The researchers uses both types of evaluations in designing and developing the LAPTS. The formative evaluation was applied throughout the whole process to examine the functionality of the LAPTS and feedbacks were amended during the developmental phase. While the summative evaluation was carried out after the final version of the instruction was implemented in order to assess the overall effectiveness of the LAPTS which tell the researchers whether or not the LAPTS successfully developed students' mathematical thinking in linear algebra.

\section{Methodology}

The present research employed both quantitative and qualitative data to elucidate the experts' evaluation of the LAPTS instruction prior to the final implementation of the strategy in the classroom. Quantitative data were obtained to verify the effectiveness of the learning strategy by giving students of both experimental and control groups the same post-test. However, it can be said that the best way to evaluate the content validity is the content review of an expert [53]. Experts' content evaluation was conducted after the design and development of the LAPTS. The experts are lecturers who have years of experience in teaching linear algebra as well as application of peer tutoring strategy. It is believed that the sufficient number of reviewer for content validity is from 5-10 persons [54-56].

\section{Results}

\subsection{Quantitative Analysis from the Students' Post-Test Scores}

The quantitative scores obtained were analyzed statistically at $\alpha=0.05$ level of significance using mean, S.D. and independent sample t-test to study the differences of each mathematical thinking processes between the experimental and control groups' prost-test scores as shown in Table 1.

Table 1. T-Test of the Posttest Scores for Each Mathematical Thinking Process (MTPs) of Both Groups

\begin{tabular}{|c|c|c|c|c|c|c|c|c|}
\hline $\begin{array}{c}\text { Mathematical Thinking } \\
\text { Processes (MTPs) }\end{array}$ & Group & $\mathrm{N}$ & Mean & S. D. & df & t-value & $\mathrm{P}$ & Remark \\
\hline \multirow{2}{*}{ Specializing } & Experimental & 36 & 13.90 & 1.87 & \multirow{2}{*}{71} & \multirow{2}{*}{7.162} & \multirow{2}{*}{0.000} & \multirow{2}{*}{ Sig. } \\
\hline & Control & 37 & 10.95 & 1.65 & & & & \\
\hline \multirow{2}{*}{ Generalizing } & Experimental & 36 & 12.13 & 1.16 & \multirow{2}{*}{71} & \multirow{2}{*}{10.887} & \multirow{2}{*}{0.000} & \multirow{2}{*}{ Sig. } \\
\hline & Control & 37 & 8.74 & 1.48 & & & & \\
\hline \multirow{2}{*}{ Conjecturing } & Experimental & 36 & 16.31 & 1.22 & \multirow{2}{*}{71} & \multirow{2}{*}{14.610} & \multirow{2}{*}{0.000} & \multirow{2}{*}{ Sig. } \\
\hline & Control & 37 & 11.38 & 1.63 & & & & \\
\hline \multirow{2}{*}{ Convincing } & Experimental & 36 & 10.90 & 1.20 & \multirow{2}{*}{71} & \multirow{2}{*}{2.497} & \multirow{2}{*}{0.015} & \multirow{2}{*}{ Not Sig } \\
\hline & Control & 37 & 10.07 & 1.62 & & & & \\
\hline
\end{tabular}


Table 1 used independent-sample t-test statistic to analyze the posttest scores of both experimental and control groups with regards to each mathematical thinking processes. It is clear that the students demonstrated some elements of mathematical thinking processes after the posttest as the outcome of the analysis was significant in three out of the four mathematical thinking process. For specializing, Table 1 indicates that the posttest mean scores of experimental and control groups are $(M=13.90$, S.D. $=1.87)$ and $(M=10.95$, S.D. $=1.65)$ respectively with a difference in mean of 2.95 . This difference at $\mathrm{t}(71)=7.162$, and $p<0.001$ was found to be statistically significant. The Cohen's $\mathrm{d}$ for this test was 0.95 , which in mean difference can be described as a large effect size $[57,58]$.

Furthermore, generalizing in Table 1 shows the posttest mean scores of experimental and control groups are $(\mathrm{M}=12.13, \quad$ S.D. $=1.16) \quad$ and $\quad(\mathrm{M}=8.74, \quad$ S.D. $=1.48)$ respectively with a difference in mean of 3.39 . This difference at $\mathrm{t}(71)=10.887$, and $\mathrm{p}<0.001$ was found to be statistically significant. The Cohen's $d$ for this test was 1.92 , which in mean difference can be described as a large effect size [57, 58]. However, the outcome of conjecturing, Table 1 shows the posttest mean scores of experimental and control groups as $(\mathrm{M}=16.31, \mathrm{~S} . \mathrm{D} .=1.22)$ and $(\mathrm{M}=11.38$, S.D. $=1.63$ ) respectively, with a mean significant difference of 4.93. This difference at $t(71)=14.610$, and $p<0.001$ was found to be statistically significant. The Cohen's $d$ for this test was 2.38 , which in mean difference can be described as a large effect size $[57,58]$. But surprisingly, convincing shows a totally different result in Table 1 as there is no significant differences $($ sig. value $=0.015)$ between the posttest mean scores of experimental and control groups $(\mathrm{M}=10.90, \quad$ S.D. $=1.20) \quad$ and $\quad(M=10.07, \quad$ S.D. $=1.62)$ respectively, with a difference in mean of 0.83 . This difference at $\mathrm{t}(71)=2.497$, and $\mathrm{p}>0.001$ was found to be statistically not-significant. The Cohen's $d$ for this test was 0.41 , which in mean difference can be described as a medium effect size $[57,58]$.

\subsection{Quantitative Analysis from the Experts Content Evaluation}

The LAPTS was given to eight experts in order to provide their comments and suggestions based on the content and activities that will be perform by tutors and tutees. Columns were provided for experts' comments and observations; whereas modification were made based on their comments and observation. Furthermore, evaluation form with three likert scale rating of "Yes, Need modification, and No" was provided during formative evaluation with weighting ranging from 3 to 1 respectively. The highest possible mean score is 3.00 , the lowest mean score is 1.00 and the scores range is 2.00 . When a mean score of an item is $>2$ it is considered positively cued item and vice versa for negatively cued item with mean score $<2$. Scores obtained from each item were analyze using descriptive statistic of mean and standard deviation as shown in Table 2.

Table 2. Summary of the Content Evaluation Based on the Experts Rating

\begin{tabular}{|c|l|c|c|}
\hline Item & \multicolumn{1}{|c|}{ Content evaluation } & Mean & S. D. \\
\hline 1 & The objectives of the learning strategy (LAPTS) and the instruments is understood. & 3.00 & 0.000 \\
\hline 2 & The content of the LAPTS is relevant to the concept asked. & 3.00 & 0.000 \\
\hline 3 & $\begin{array}{l}\text { The learning activities in the LAPTS encourage students to use their mathematical } \\
\text { thinking processes. }\end{array}$ & 3.00 & 0.000 \\
\hline 4 & Students can understand the steps in the LAPTS easily because it is direct and clear. & 2.87 & 0.354 \\
\hline 5 & The content of the LAPTS has been designed and developed thoroughly. & 2.87 & 0.354 \\
\hline 6 & The activity in the LAPTS can encourage collaboration and independent learning. & 2.87 & 0.354 \\
\hline 7 & $\begin{array}{l}\text { The content in LAPTS provides and give students the opportunity to solve problems } \\
\text { with their own ideas. }\end{array}$ & 2.87 & 0.354 \\
\hline 8 & $\begin{array}{l}\text { The instruments format is appropriate and are within the scope of the research } \\
\text { questions. }\end{array}$ & 2.87 & 0.354 \\
\hline 9 & $\begin{array}{l}\text { The research instruments fits with the variables under investigation, thus measuring } \\
\text { what it tends to measure. }\end{array}$ & 2.87 & 0.354 \\
\hline 10 & $\begin{array}{l}\text { The instruments have the capability to measure items of variable within a given time } \\
\text { frame. }\end{array}$ & 3.00 & 0.000 \\
\hline 11 & The instruments have the ability to gather factual data eliminating bias and subjectivity. & 3.00 & 0.000 \\
\hline 12 & $\begin{array}{l}\text { The instruments have the capability of generating data that will be of value and } \\
\text { practical use in education. }\end{array}$ & 3.00 & 0.000 \\
\hline Average & $\begin{array}{l}|c| \\
\text { Number of experts (N) = }\end{array}$ & 0.177 \\
\hline
\end{tabular}


The results obtained in Table 2 shows a highly positive and encouraging results due to the high mean ratings. The highest mean scores obtained is 3.00 , while the lowest is 2.87 , which means that all the responses were highly positive for each item validity. This is evidenced by the average means and standard deviation which happens to be 2.94 and 0.177 respectively. Most of the expert agreed that the content and lesson organization of the LAPTS is found to be compatible with the objectives and appear to develop mathematical thinking among polytechnic students.

To ensure the LAPTS and the research instruments have a good content validity, the study further used Fleiss' kappa coefficient. Fleiss' kappa coefficient works are based on three or more inter-rater agreement for each item [59]. The possible values for kappa $(\mathrm{k})$ statistic ranges from -1 to 1 with $-1,0,1$ indicating perfect disagreement, completely random agreement and perfect agreement respectively. Ref [56], [60, 61] provide the following rules for interpreting kappa values: $<0.00$ is poor agreement, $0.00-0.20$ is slight agreement, $0.21-0.40$ is fair agreement, $0.41-0.60$ is moderate agreement, $0.61-0.80$ is substantial agreement, $0.81-1.00$ is almost perfect agreement. Moreover, [54-56] provide more conservative interpretation suggesting that conclusions should be discounted for variables with values less than 0.67 , tentative conclusions should be made for values between $0.67-0.80$, whereas definite conclusions should be made for values above 0.80 . Table 3 below shows the content validity for the Fleiss' kappa coefficient.

Table 3. Kappa Statistics

\begin{tabular}{|c|c|c|c|}
\hline Scale & Items & Kappa & Decision \\
\hline $\begin{array}{c}\text { LAPTS \& Research } \\
\text { instruments }\end{array}$ & 12 & 0.76 & $\begin{array}{c}\text { Substantial } \\
\text { agreement }\end{array}$ \\
\cline { 2 - 3 } & Total & 0.76 & s. \\
\hline
\end{tabular}

\subsection{Qualitative Analysis from the Experts Content Evaluation}

Consequently, the qualitative data were obtained based on interview with four experts so as to get detailed feedback on the LAPTS contents. Analysis of the verbatim quotes was carried out using inductive coding approach by identifying themes as shown in Table 4. 
Table 4. Experts' Comments Regarding their Views about the LAPTS

\begin{tabular}{|c|c|c|c|c|}
\hline $\begin{array}{c}\text { Validator } \\
\text { Date }\end{array}$ & Verbatim quotes & Codes & Sub-theme & Theme \\
\hline $\begin{array}{c}1 \\
24 / 04 / 19\end{array}$ & $\begin{array}{l}\text { (i). "Well, going through the content, the construct design and even the } \\
\text { number of questions that you restrict yourself to, adhered to our own way } \\
\text { of comprehending things. I believe ..... the content validity is OK". } \\
\text { (ii). "As long as you will adhere to what I have seen written in the lesson } \\
\text { plan and what is brought in the instrument too, ... I believe a good result } \\
\text { can be obtained". } \\
\text { (iii). "One of the thing that drew my attention is the convincing. Ermm ... } \\
\text { convincing can be more obtained between peers than some body in high } \\
\text { hierarchy but if peers are fused together, I believe they can be able to } \\
\text { convince themselves". } \\
\text { (iv). "The stages of the implementation design if adhered to, ...... the rob } \\
\text { minds ammm fertilization of ideas can be realized". } \\
\text { (v). "The quality of students" oral explanation can be obtained if the tutors } \\
\text { comprehend what is exactly planned in the lesson plan". }\end{array}$ & $\begin{array}{l}\text { The content, the construct design } \\
\text { adhered to our own way of } \\
\text { comprehending things. Is OK } \\
\text { If you adhere to the lesson plan a good } \\
\text { result can be obtained. } \\
\text { Convincing can be more obtained } \\
\text { between peers while working } \\
\text { collaboratively. } \\
\text { Sharing of ideas and peer } \\
\text { collaboration can be obtained. } \\
\text { It develops self-confidence among } \\
\text { students. }\end{array}$ & $\begin{array}{l}\text { It is satisfactory } \\
\text { A good result can be obtained. } \\
\text { Convincing can be more } \\
\text { obtained through peer } \\
\text { collaboration } \\
\text { It encourages peer } \\
\text { collaboration } \\
\text { It promotes self-confidence }\end{array}$ & \multirow[t]{2}{*}{ Encourages peer collaboration } \\
\hline $\begin{array}{c}2 \\
29 / 04 / 19\end{array}$ & $\begin{array}{l}\text { (i). "I'm impressed with the learning strategy because students can } \\
\text { understand the steps involve in it easily which makes it clear and direct". } \\
\text { (ii). "I personally believe that the content in the learning strategy is } \\
\text { relevant to the linear algebra topics and the learning strategy will be able } \\
\text { to develop students' mathematical thinking processes, in a peer tutoring } \\
\text { strategy classroom setting". } \\
\text { (iii). "The level of students' engagement in small groups will be } \\
\text { developed, because of the mutual interaction between tutor and tutees". } \\
\text { (iv). "Tutees will be able to feel free, ...... will also be able to ask } \\
\text { questions with regards to their friends', presentation and even in some } \\
\text { instances be able to joke between one another, speak their various } \\
\text { languages". } \\
\text { (v). "The tutor will as well benefit from this relationship in such a way } \\
\text { that he will make sure he masters the part given to him using the learning } \\
\text { strategy". } \\
\text { (vi). "Using the learning strategy to evaluate their work will help them in } \\
\text { improving their mathematical thinking skills". } \\
\text { (vii). "The quality of the tutor's oral explanation will be improved in such } \\
\text { a way that he will develop self confidence among his peers. This is } \\
\text { because he has mastered the topic area and also familiarized himself with } \\
\text { all the terms and manipulations within the topical area". }\end{array}$ & $\begin{array}{l}\text { Students can understand the steps } \\
\text { involved in the learning strategy } \\
\text { easily. } \\
\text { The learning strategy will be able to } \\
\text { develop students mathematical } \\
\text { thinking processes. } \\
\text { Students' engagement in small groups } \\
\text { will be developed because of the } \\
\text { mutual interaction. } \\
\text { They can make jokes between one } \\
\text { another } \\
\text { He will make sure he masters the part } \\
\text { given to him } \\
\text { Mathematical thinking skills will be } \\
\text { improved } \\
\text { He has mastered the topic area and } \\
\text { also familiarized himself with all the } \\
\text { terms and manipulations within the } \\
\text { topical area. }\end{array}$ & $\begin{array}{c}\text { It is satisfactory } \\
\text { Specializing } \\
\text { Generalizing } \\
\text { Conjecturing } \\
\text { Convincing } \\
\text { It encourages peer } \\
\text { collaboration } \\
\text { Freedom }\end{array}$ & \\
\hline $\begin{array}{c}3 \\
30 / 04 / 19\end{array}$ & $\begin{array}{l}\text { (i). "This linear algebra peer tutoring strategy is a very good innovation". } \\
\text { (ii). "It will increase them in mastery of their assign task .... and also } \\
\text { increase their confidence among their peers". } \\
\text { (iii). "I think the learning strategy is user-friendly". } \\
\text { (iv). "This linear algebra peer erm peer tutoring strategy seems to have a } \\
\text { good relationship between tutor and tutees .... through reciprocal mutual } \\
\text { interaction". } \\
\text { (v). "I think, the use of ermm a structured and a step-by-step document } \\
\text { like this will improve the students' thinking skills as well as their } \\
\text { engagements in small group activities". } \\
\text { (iv). "Students oral explanation will also be improve when using the } \\
\text { learning strategy". }\end{array}$ & $\begin{array}{l}\text { Is a good innovation } \\
\text { Mastery of their assign task. } \\
\text { Increase their confidence } \\
\text { Is user-friendly } \\
\text { The LAPTS seems to have a good } \\
\text { relationship between tutor and tutees. } \\
\text { Peer collaboration and mathematical } \\
\text { thinking skills will be improved. } \\
\text { Developing self-confidence. }\end{array}$ & $\begin{array}{l}\text { Is a good innovation } \\
\text { It promotes self-confidence } \\
\text { Freedom } \\
\text { It encourages peer } \\
\text { collaboration } \\
\text { Specializing } \\
\text { Generalizing } \\
\text { Conjecturing } \\
\text { Convincing } \\
\text { It promotes self-confidence }\end{array}$ & $\begin{array}{l}\text { Specializing } \\
\text { Generalizing } \\
\text { Conjecturing } \\
\text { Convincing }\end{array}$ \\
\hline
\end{tabular}




\section{Table 4 continued}

\begin{tabular}{|c|c|c|c|c|}
\hline $\begin{array}{c}4 \\
03 / 05 / 19\end{array}$ & $\begin{array}{l}\text { (i). "The learning strategy is a good innovation". } \\
\text { (ii). "It is far better if it is practicable to be use in smaller groups ..... as it } \\
\text { gives room for students participation". } \\
\text { (iii). "Everybody who participate, one he is able to develop his talking } \\
\text { skills, he is able to develop his confidence and he is also able to } \\
\text { appreciate that he is part and parcel of the system". } \\
\text { (iv). "Thinking ability is enhanced because now they see the learning of } \\
\text { algebra in a totally different perspective and then it removes that natural } \\
\text { fear that is attached to mathematics". } \\
\text { (v). "Whoever is the leader naturally has an advantage because it is an } \\
\text { opportunity to sharpen his skills .... in terms of coherent understanding } \\
\text { and articulation of issues". }\end{array}$ & $\begin{array}{l}\text { Is a good innovation. } \\
\text { It is far better if it is practicable } \\
\text { through peer collaboration. } \\
\text { Everybody who participate will work } \\
\text { collaboratively among his peers and as } \\
\text { well develop self-confidence. } \\
\text { Mathematical thinking ability is } \\
\text { enhanced. } \\
\text { The tutor will make sure he master the } \\
\text { part given to him before teaching it to } \\
\text { his peers. }\end{array}$ & $\begin{array}{l}\text { Is a good innovation } \\
\text { It encourages peer } \\
\text { collaboration } \\
\text { It promotes self-confidence } \\
\text { Specializing } \\
\text { Generalizing } \\
\text { Conjecturing } \\
\text { Convincing } \\
\text { He will make sure he masters } \\
\text { the part given to him. }\end{array}$ & Promotes self-confidence \\
\hline
\end{tabular}


Table 4 shows the analysis of experts' comments regarding their views about LAPTS. Most of the comments about LAPTS by the experts appeared to be positive such as the learning strategy is "satisfactory, encourages peer-collaboration, good innovation, freedom, develops students' mathematical thinking processes, promotes self-confidence". The experts agreed that the lesson organization in the LAPTS can provide collaborative and active learning that will improve students' mathematical thinking processes. Table 5 provides suggestions from the experts on how to improve the linear algebra peer tutoring strategies.

Table 5. Experts' Suggestions on Improving the LAPTS and the Research Instruments

\begin{tabular}{|c|c|}
\hline Item & Suggestions \\
\hline \multirow{5}{*}{$\begin{array}{l}\text { Linear algebra } \\
\text { peer tutoring } \\
\text { strategy } \\
\text { (LAPTS) }\end{array}$} & $\begin{array}{l}\text { There is the need to explain further the role of } \\
\text { tutors' when it comes to application of the steps } \\
\text { of Medcalf model (watch, ask, show and praise) } \\
\text { with regards to solving questions provided in } \\
\text { each lesson. }\end{array}$ \\
\hline & $\begin{array}{l}\text { The exercises provided in the learning strategy } \\
\text { should focus more on developing individuals' } \\
\text { mathematical thinking processes even though } \\
\text { the teaching approach is peer tutoring but the } \\
\text { students' individual mathematical thinking } \\
\text { processes are to be evaluated. }\end{array}$ \\
\hline & $\begin{array}{l}\text { The exercises should be in a way that one } \\
\text { question should be solve among group members } \\
\text { collectively, while the remaining two questions } \\
\text { should be solve individually in order to improve } \\
\text { their thinking processes. }\end{array}$ \\
\hline & $\begin{array}{l}\text { There is the need to give more priority to vector } \\
\text { spaces and linear transformations as they are } \\
\text { widely applicable in many engineering fields. }\end{array}$ \\
\hline & $\begin{array}{l}\text { Being you a Nigerian, I believe you can be able } \\
\text { to consider the prevailing conditions of learning } \\
\text { and adhered to, so that this strategy can work } \\
\text { effectively and efficiently. }\end{array}$ \\
\hline $\begin{array}{l}\text { Research } \\
\text { instruments }\end{array}$ & $\begin{array}{l}\text { Add 30minutes to the research instruments since } \\
\text { the students are to attempt all questions. }\end{array}$ \\
\hline
\end{tabular}

\section{Discussion}

An investigation of the students' understanding in linear algebra was earlier conducted and it was found to be low because of the continued poor performance in their semester examinations which is attributed to method of teaching which appeared to be mostly conventional lecturing method [12], [62, 63]. This prior knowledge have different effects on learning [64-67] in such a way that misguided prior knowledge if not corrected can hinder students from understanding the newly acquired concept leading to mismatch between the new and old concept [68]. The developed learning instruction (LAPTS) detects prior knowledge at early stages through the preliminary investigations that was carried out (on the conventional methods of teaching and learning) in order to identify students' prior knowledge in a polytechnic linear algebra subject as well as justify the need for the design and development.

To achieve the objectives of this study, a learning strategy (LAPTS) was developed through a systematic process [33], consisting of a set of guidelines that describe the way the classroom instruction would be carried out in different settings [34, 35]. The model used in the development of the classroom learning instruction in this study is ADDIE model. In the analysis phase (the first phase), the researchers examined the need to incorporate peer tutoring strategy in a linear algebra classroom to develop polytechnic students' mathematical thinking processes. Based on the activities performed in the preliminary study, it is evident that there is the need for a learning strategy that will allow students to work collaboratively in order to develop their mathematical thinking processes as the conventional learning was identify to have some challenges in achieving this objective. This view is congruent with the view of [25], [64, 65], [69-72] whereby they agreed that in designing a learning strategy, there is a need to overcome the detected problem at an early stage (i.e. before formulating and implementing the pedagogical instructions in the classroom) to facilitate meaningful and successful learning. In the design and development phases (the second and third phases), the researchers decided on the materials, lessons, and content that are needed to be covered, the different goals to be achieved during the program, as well how these goals can be reached.

The researchers gathered all the information as well as the materials needed and developed the lessons into one guide to make the instruction more effective, efficient, appealing, significant, and less rigorous $[34,35]$. The LAPTS was designed to make all students to become active participant in class through communication with their peers, questioning, experimenting, and exploring. Topics on linear algebra were distributed randomly to every member of each group to be practiced and be ready to function as tutors and tutees. This is to ensure that they familiarize themselves with the LAPTS quickly, as they apply it throughout the intervention period which is the fourth phase (implementation phase). The final phase (evaluation phase) measure the effectiveness and efficiency of the instruction as it give the researchers the opportunity to monitor how students' understandings have progressed through administration of test or performance activities [48-51].

Consequently, the LAPTS exposed the students to numerous ideas and allowed them to exchange such ideas in a broader context leading to widening of their understanding of the learning content. The content indicates that LAPTS have the potential of being better understood, internalized and retained than the one taught with conventional method where students are just passive learners because the activities in the LAPTS are designed to enhance students' mathematical thinking processes through peer collaboration in a linear algebra classroom 
setting. Ref [73] stated that it was easier to stimulate non-active students in smaller collaborative groups, and promotes higher sense of presence and engagement, and increased individual contributions. However, this study revealed that the interactions between group members in the LAPTS were consistent and discussions were focused on the same topic until the students reached conclusions. Furthermore, the research revealed that the discussions were initiated and led by tutors' of each group seeking further explanations, giving opinions or making decisions in the LAPTS as well as assisting their fellow peers in their knowledge building. Nevertheless, the LAPTS contribute to the students' learning in linear algebra as the results of this study showed that the developed learning instruction is effective in developing students' performance as well as their mathematical thinking processes. These results agree with researches done by [9], [25], [62, 63], [69], [71, 72], [74], that a well designed and developed collaborative learning instruction can effectively improve students' performance by allowing learners to deepen and develop their knowledge. Although, all students seemed to be actively involved throughout the process as the developed learning strategy guided them in enhancing their mathematical thinking processes.

Moreover, experts' content evaluation was conducted after the design and development of the LAPTS as [53] pointed out that the best way to evaluate the content validity is through the content review of experts; whereas the number of experts' are expected to range from 5-10 persons [54-56]. The LAPTS was given to eight validators whom are lecturers with years of experience in teaching linear algebra as well as application of peer tutoring strategy to provide their comments and suggestions based on the content and activities that will be performed by tutors and tutees. Evaluation form with three-Likert scale rating of "Yes, Need modification, and No" was provided to them; and interviews were also conducted with four of the validators. Scores obtained from each item on the validator's forms were analyzed using descriptive statistic of mean and standard deviation. The outcome of the analysis revealed a highly positive and encouraging results as all the mean scores were high as shown in Table 2. The content analysis revealed that the validators agreed that the lesson organization in the LAPTS can provide collaborative and active learning that will develop students' mathematical thinking processes. Furthermore, the comments from the interviews with the validators about the LAPTS also demonstrated positive impression (see Table 4) consisting of "satisfactory, encourages peer-collaboration, good innovation, develops self-confidence, gives room for freedom, good result can be obtained while using it".

Accordingly, the validators are of the opinion that mathematical thinking processes can be improve as noted in their interviews that "convincing can be more obtained between peers than some body in high hierarchy" who seems to be their teacher. This means that meaningful learning experience and good result can be obtained from the developed learning strategy as evidenced in Table 4. Ref [75] found out that meaningful learning experience can be develop only when the learners are bind together in active discussion and negotiation. Ref [76] discovered that learning appeared to be most effective when students were actively involved in their knowledge through collaboration. Ref [77] asserted that this was the best approach to implement particularly in higher education, so as to encourage active participation in learners in a collaborative way. The results are consistent with the reported findings of [9], [29-31], [62, 63], [74], [78] who commented that active social interaction between the learners and instructors, or more knowledgeable peers, helped in improving learners thinking about a subject.

The second objective of this research is to look at how effective is the LAPTS in developing students' mathematical thinking by evaluating their performance in linear algebra based on Mason's mathematical thinking processes. The current situation in the mathematics classroom is simply focusing on mathematical structures rather than developing students' various thinking skills [79]. The result of the independent sample t-test from Table 1 showed that three out of the four mathematical thinking processes where statistically significant. This means that, specializing, generalizing and conjecturing were the successful mathematical thinking processes during this study as there Cohen's d values for the test appeared to have an effect size that is large in the difference of mean $[57,58]$. According to [24], if the process of specialization happens successfully via a useful conjecturing, it can be helpful in making generalization. This result is in line with the findings of [9], [79], [80-82] who found out that promoting the actions of specializing and generalizing can promote the use of students' own powers to make sense of mathematics as well as predict about relationships.

\section{Conclusions}

It can be concluded that using LAPTS for students learning in linear algebra classroom helps to improve their performances as well as their mathematical thinking processes. The findings conform to the findings of [83, 84], whom described mathematical thinking as a way of improving understanding and extending control over the study of mathematics. It is clear from the validators' point of view that "collaborative settings have great potential in developing students' mathematical thinking processes". They believed that the content in the LAPTS is relevant to the linear algebra topics and the learning strategy will be able to develop students' mathematical thinking processes in a peer tutoring strategy classroom setting. It was also pointed out that "the use of a structured and a step-by-step document like LAPTS will improve the students' thinking skills as well as their engagements in small group activities 
as it seems to have a good relationship between tutor and tutees through reciprocal mutual interaction". This mutual interaction between tutors- and tutees was considerably beneficial to learners, as they were exposed to each other's various ideas and opinions. The contradictions between their own perception and others' insight allowed them to think deeper and enhanced their mathematical thinking processes. Therefore students played an important role in the development of their mathematical thinking processes while educators are expected to assist and facilitate them throughout the learning process. Moreover, "when students comprehend what is exactly planned in the lesson plan, the quality of their oral explanation will be improved in such a way that they will develop self confidence among their peers. Besides, all students mastered the topic area and they also familiarized themselves with all the terms and manipulations within the topical area".

\section{REFERENCES}

[1] Umar, B. S. (2014). A Cognitive Analysis of Problem-Based Learning in Teaching Mathematics at Senior Secondary School Level. Unpublished $\mathrm{PhD}$ Thesis; Usmanu Danfodiyo University Sokoto.

[2] Admon, N. D., Abu, M. S., Mokhtar, M., Abdullah, A. H. \& Atan, N. A. (2015). Enhancing Higher Order Thinking Skills through Mathematical Thinking in an Outside Classroom Learning Environment: A Theoretical Framework. Proceedings of the $2^{\text {nd }}$ International Education Postgraduate Seminar (IEPS 2015), December 20-21, Pulai Spring Resort, Johor Bahru, Malaysia.

[3] Karadag, Z. (2009). Analyzing Students' Mathematical Thinking in Technology Supported Environments. Published PhD Thesis, Submitted to University of Toronto.

[4] Schoenfeld, A. H. (2007). Problem Solving in the United States, 1970-2008: Research and Theory, Practice and Politics. ZDM Mathematics Education; 39, 537-551.

[5] Musa, A. (2015). A Systematic Attempt to Establishing the Fear and Poor Performance of Students Linear Algebra. A paper presented at the $48^{\text {rd }}$ Annual Conference of Mathematical Association of Nigeria, Held at University of Nigeria, Nsuka.

[6] Yahaya, A. K. (2014). Application of Linear Algebra in everyday Life. A Paper Presented at National Mathematical Centre (NMC) supported by Petroleum Technology Development Fund (PTDF). Workshop for Tertiary Institution Lecturers at Abuja, 17 $7^{\text {th }}-22^{\text {nd }}$ May, 2014.

[7] Bourne, A. (2014). Development of the Academic Performance Commitment Matrix (APCM): Understanding the Effects of Motivation and an Engineering Mathematics Curricular Intervention on Student Self-Efficacy and Success in Engineering.

[8] Herrington, J., Reeves, T. C. \& Oliver, R. (2014). Authentic Learning Environments. Handbook of Research on Educational Communications and Technology (pp.
401-412): Springer.

[9] Muhammad, S. A., Abdullah, A. H. \& Osman, S. (2020). Developing Mathematical Thinking among Polytechnic Students in Linear Algebra through Peer Tutoring Strategy. Journal of Advanced Research in Dynamical and Control Systems; 12(3), 423-434. DOI: 10.5373/JARDCS/V12I3/2 0201210

[10] Dvorak, J. (2004). Managing Tutoring Aspects of the Learning Assistance Center. Research for Educational Reform; 9(4), 39-51.

[11] Ogbuanya, T. C., Bakare, J. A. \& Igweh, A. U. (2009). Reciprocal Peer Tutoring and Academic Achievement of Students in the Development of Mathematical Thinking among Technical Colleges in South West Nigeria. Nigerian Vocational Journal; 14(1), 98-106.

[12] Sani, M. A., Abdullah, A. H., Osman, S., Ali, D. F., Samah, N. A., Jumaat, N. F., Ashari, Z. M. \& Umar, H. A. K. (2020). A Systematic Review on the Impact of Peer Tutoring Strategy in Linear Algebra among Polytechnic Students. Journal of Critical Reviews; 7(6), 298-305. DOI: $10.31838 /$ jcr.07.06.52

[13] Eda, D. \& Nesibe, A. K. (2014). The Critical Thinking Dispositions of Prospective Science and Mathematics Teachers. Social and Behavioral Sciences; 116(2014), 1551-1555.

[14] Florica, C. (2004). Critical Thinking in Algebraic Concepts. Bucharest: Center for Education, Gloria Publishing.

[15] Craft, A., Cremin, T., Burnard, P., Dragovic, T. \& Chappell, K. (2012). Possibility Thinking: Culminative Studies of an Evidence-based Concept Driving Creativity? Education 3-13. International Journal of Primary, Elementary and Early Years Education; 40(7), 1-19.

[16] Wilson, M. L. (2011). Students' Learning Style Preferences and Teachers' Instructional Strategies: Correlations between Matched Styles and Academic Achievement. A Thesis Presented in Partial Fulfillment of the Requirements for the Degree of Doctor of Education in Liberty University, Lynchburg V.A.

[17] Chukwuyenum, A. N. (2013). Impact of Critical Thinking on Performance in Mathematics among Senior Secondary School Students in Lagos State. Journal of Research and Methods in Education; 3(5), 18-25.

[18] Dioso-Henson, L. (2012). The Effect of Reciprocal Peer Tutoring and Non-Reciprocal Peer Tutoring on the Performance of Students in College Physics. Research in Education; 87(1), 34-49.

[19] Zapalska, A. \& Dabb, H. (2002). Learning Style. Journal of Teaching in International Business; 13(3/4), 77-97. Retrieved from Education Research Complete database.

[20] Vygotsky, L. S. (1978). Mind in Society: The Development of Higher Psychological Processes. Cambridge, MA: Harvard University Press.

[21] Medcalf, J. (1992). Peer Tutoring in Reading. Hastings: Medcalf Press.

[22] Medcalf, J. (1994). Peer Tutoring in Written Language. Hastings: Medcalf Press. 
[23] Medcalf, J. (1995). Cooperative Learning and Peer Tutoring Strategies for Inclusive Education. Reading Forum; 2, 11-19.

[24] Mason, J., Burton, L. \& Stacey, K. (2010). Thinking Mathematically (2 ${ }^{\text {nd }}$ Ed.). Edinburgh: Pearson Education Limited.

[25] Huitt, W. G. (2000). A Constructivistic Approach to Learning [PowerPoint]. CA: Valdosta State University.

[26] Elshof, L. (2001). Teacher's Interpretation of Sustainable Development. International Journal of Technology and Design Education; 15, 102-116.

[27] Lai, E. (2011). Critical Thinking: A Literature Review. Pearson Research Report. Retrieved June 2018 from http://www.pearsonassessments.com/.pdf.

[28] Kudzai, C., Christmas, D. \& Josiah, M. (2013). Vygotsky's Zone of Proximal Development Theory: What are its Implication for Mathematical Teaching? Greener Journal of Social Sciences; 3(7), 371-377.

[29] Wass, R. T. (2012). Developing Critical Thinkers in Higher Education: A Vygotskian Perspective. A Published PhD. Thesis, Submitted to University of Otago Dunedin, New Zealand.

[30] Wass, R. T., Harland, T. \& Mercer, A. (2011). Scaffolding Critical Thinking in the Zone of Proximal Development. Higher Education Research and Development; 30(3), 317-328.

[31] Velez, J. J., Simonsen, J. C., Cano, J. \& Connors, J. J. (2010). Teaching Partnerships: The Use of Peer Facilitators in the College Classroom to Facilitate Thinking Skills. Journal of Agricultural Education; 51(4), 49-55.

[32] Chuen, T. W. (2006). Development and Evaluation of a Web-Based Learning System Based on Learning Object Design and Generative Learning to Improve Higher-Order Thinking Skills and Learning. A PhD Thesis, submitted to the Faculty of Education, Universiti Teknologi Malaysia.

[33] Gustafon, K. L. \& Branch, R. M. (2002). What is Instructional Design? In R. A. Reiser, \& J. V. Damsey (Eds.). Trends and Issues in Instructional Design and Technology. Columbus, Ohio: Merrill Prentice Hall.

[34] Moallem, M. (2001). Applying Constructivist and Objectivist Learning Theories in the Design of a Web-Based Course: Implications for Practice. Educational Technology and Society; 4(3), 73-81.

[35] Bichelmeyer, B. (2005). The ADDIE Model: A Metaphor for the Lack of Clarity in the Field of Integrated Device Technology. Paper Presented at the Annual Conference of the Association for Educational Communications and Technology, Chicago, IL. Retrieved August 2018 from http://www.unco.edu/CETL/sir/clt/documents/IDTf_Bic.p df.

[36] McGriff, S. J. (2000). Instructional System Design (ISD): Using the ADDIE Model. Retrieved October 11, 2018 from http://www.personal.psu.edu/faculty/s/j/sjm256/portfolio/k base/IDD/ADDIE.pdf.

[37] Twilley, J. (2014). An Examination of the Practice of Instructional Design and the Use of Instructional Design Models. A Published PhD Theses Submitted to the
University of Central Florida, Orlando, Florida.

[38] Molenda, M. (2003). Educational Technology: An Encyclopedia. In A. Kovalchick, \& K. Dawson, (Eds.). Santa Barbara, CA: ABC-Clio.

[39] Naganathan, V. \& Wong, K. C. (2012). Overview of Instructional Design Model: Issues and Challenges. International Journal of Research in Management and Technology; 2(3), 324-333.

[40] Huang, C. I. (2015). A Collaborative Metacognitive Community Model in Improving Higher Level Thinking Skills. A PhD. Thesis Submitted to the Faculty of Education, Universiti Teknologi Malaysia.

[41] Piskurich, G. M. (2015). Rapid Instructional Design: Learning Instructional Design Fast and Right ( $3^{\text {rd }}$ Ed.). Hoboken, NJ, USA: John Wiley \& Sons.

[42] Alzahrani, T. \& Leko, M. (2018). The Effects of Peer Tutoring on the Reading Comprehension Performance of Secondary Students with Disabilities: A Systematic Review. Reading \& Writing Quarterly; 34, 1-17, DOI: 10.1080/10573569.2017.1302372.

[43] Lyttle, L. A. (2011). Do Peer Tutors Help Teach ESOL Students to Learn English as a Second Language more successfully? Retrieved May 2018 from ERIC database. (ED518172).

[44] Nawaz, A. \& Rehman, Z. U. (2017). Strategy of Peer Tutoring and Students' Success in Mathematics: An Analysis. Journal of Research and Reflection in Education; 11(1), 15-30.

[45] Wolfe, B. (2018). The Impact of a Peer-Tutoring Model on the Academic Performance of Secondary Students. Doctoral dissertation submitted to University of South Carolina.

Retrieved September 2019 from https://scholarcommons.sc .edu/etd/4468.

[46] Fraenkel, J. R. \& Wallen, N. E. (2008). How to Design and Evaluate Research in Education ( $7^{\text {th }}$ Ed.). New York: McGraw Hill.

[47] McBurney, D. H. \& White, T. L. (2010). Research Methods. Belmont, CA: Wadsworth, Cen-Gage Learning.

[48] Bybee, R. (2009). The BSCS 5E Instructional Model and $21^{\text {st }}$ Century Skills: A Commissioned Paper Prepared for a Workshop on Exploring the Intersection of Science Education and Development of the $21^{\text {st }}$ Century Skills. Retrieved October 2019 from http://www7.nationalacadem ies.org/bose/Bybee_21st\%20Century_Paper.pdf.

[49] Bybee, R., Taylor, J., Gardner, A., Scotter, P., Powell, J. \& Westbrook, A. (2006). The BSCS 5E Instructional model: Origins, Effectiveness, and Applications. Retrieved October

2019 from http://www.bscs.org/pdf/bscs5eexecsummary.p df.

[50] Eisenkraft, A. (2003). Expanding the 5E Model. The Science Teacher; 70(6), 56-59.

[51] Nor, M. N. (2014). Development of a Classroom Instruction Based on Constructivist 5E-Learning Cycle Approach to Enhance Students' Conceptual Understanding in Data Communications and Networking. PhD Thesis; Submitted 
to the Faculty of Education, Universiti Teknologi Malaysia.

[52] Birisci, S. \& Metin, M. (2010). Developing an Instructional Material Using a Concept Cartoon Adapted to the 5E model: A sample of Teaching Erosion. Asia-Pacific Forum on Science Learning and Teaching; 11(1), 1-15.

[53] Shuttleworth, M. (2009). Content Validity. Retrieved May 2018 from Experiment Resources: http://www.experimentresources.com/content-validity.html.

[54] Gamer, M., Lemon, J., Fellows, I. \& Sing, P. (2010). IRR: Various Coefficients of Inter-Rater Reliability and Agreement. Retrieved April 2019 from http://CRAN.R-project.org/package=irr.

[55] Gwet, K. (2002). Kappa Statistic is Satisfactory for Assessing the Extent of Agreement between Raters. Statistical Methods for Inter-Rater Reliability Assessment; 1(6), 1-6.

[56] Hayes, A. F. \& Krippendorff, K. (2007). Answering the Call for a Standard Reliability Measure for Coding Data. Communication Methods and Measurements; 1, 77-89.

[57] Cohen, J. (1992). Quantitative Methods in Psychology: A Power Primer. Psychological Bulletin; 112(1), 155-159.

[58] Cohen, J. (1998). Statistical Power Analysis for the Behavioral Sciences. Hillsdale, NJ: Erlbaum.

[59] Lacroix, G. L. \& Giguere, G. (2006). Formatting Data Files for Repeated-Measures Analysis in SPSS: Using the Aggregate and Restructure Procedures. Tutorials in Quantitative Methods for Psychology; 2(1), 20-26.

[60] Norman, G. R. \& Streiner, D. L. (2008). Biostatistics: The Bare Essentials. Hamilton, Ontario: Decker BC.

[61] Putka, D. J., Lee, H., McCloy, R. A. \& Diaz, T. (2008). III-Structured Measurement Design in Organizational Research: Implications for Estimating Inter-Rater Reliability. Journal of Applied Psychology; 93(5), 959-981.

[62] Maduabum, M. A. \& Odili, G. A. (2011). Analysis of Students' Performance in Linear Algebra among Nigerian Institutions. Journal of Research for Curriculum Teaching; 6(2), 25-31.

[63] Marin, L. M. \& Halpern, D. F. (2011). Pedagogy for Developing Critical Thinking in Adolescents: Explicit Instruction Produces Greatest Gains. Thinking Skills and Creativity; 6, 1-13.

[64] DiCerbo, K. E. (2007). Knowledge Structures of Entering Computer Networking Students and Their Instructors. Journal of Information Technology Education; 6, 263-276.

[65] Gravoso, R. S., Pasa, A. E. \& Mori, T. (2002). Influence of Students' Prior Learning Experiences, Learning Conceptions and Approaches on their Learning Outcomes. HERDSA 2002, (pp. 282-289).

[66] Hailikari, T., Katajavuori, N. \& Lindblom-Ylanne, S. (2008). The Relevance of Prior Knowledge in Learning and Instructional Desin. American Journal of Pharmaceutical Education; 72(5), 1-8.

[67] Streveler, R., Geist, M., Ammerman, R., Sulzbach, C., Miller, R. \& Olds, B. (2006). Identifying and Investigating Difficult Concepts in Engineering Mechanics and Electric
Circuits. American Society of Engineering Education Conference. Retrieved August 2019 from http://papers.asee.org/conferences/paper-view.cfm?id=185 5.

[68] Turkmen, H. \& Usta, E. (2007). The Role of Learning Cycle Approach Overcoming Misconceptions in Science. Kastamonu Educational Journal; 15(2), 491-500.

[69] Galotti, K. M. (2011). Cognitive Development: Infancy through Adolescence. Thousand Oaks: SAGE Publication Inc.

[70] Morton, J. P., Doran, D. A. \& MacLaren, D. P. (2008). Common Student Misconceptions in Exercise Physiology and Biochemistry. Advanced Physiology Education; 32, 142-146.

[71] Sofroniou, A. \& Poutos, K. (2016). Investigating the Effectiveness of Group Work in Mathematics. Journal of Education Science; 6(4), 30-36. DOI: 10.3390/educsci6030030.

[72] Tarmizi, R. A. \& Bayata, S. (2012). Collaborative Problem-Based Learning in Mathematics: A Cognitive Load Perspective. Procedia Soc. Behav. Sci.; 32, 344-350.

[73] Hammond, M. (2000). Communication within Group Forums: The Opportunities, The Constraints and the value of a Communicative Approach. Computers and Education; $35(5), 251-262$.

[74] Nguyen, M. (2013). Peer Tutoring as a Strategy to Promote Academic Success. A Brief Research Paper Presentation at the Center for Child and Family Policy at Duke University.

[75] Razon, S., Turner, J., Johnson, T. E., Arsal, G. \& Tenenbaum, G. (2012). Effects of a Collaborative Annotation Method on Students' Learning and Learning-Related Motivation and Affect. Computers in Human Behavior; 28, 350-359.

[76] Dvorak, R. (2011). Moodle for Dummies, Indianapolis. Indiana: Wiley Publishing Inc.

[77] So, H. J., Seah, L. H. \& Toh-Heng, H. L. (2010). Designing Collaborative Knowledge Building Environments Accessible to all Learners: Impacts and Design Challenges. Computers \& Education; 54(3), 479-490.

[78] Lecusay, R., Rossen, L. \& Cole, M. (2008). Cultural-Historical Activity Theory and the Zone of Proximal Development in the Study of Idio-culture Design and Implementation. Cognitive Systems Research; 9(4), 92-103.

[79] Zeynivannezhad, F. (2014). Mathematical Thinking in Differential Equations through a Computer Algebra System. Unpublished $\mathrm{PhD}$ Thesis, submitted to the Faculty of Education, Universiti Teknologi Malaysia.

[80] Badger, M., Sangwin, C. J., Hawkes, T. O., Burn, R., Mason, J. \& Pope, S. (2012). Teaching Problem-Solving in Undergraduate Mathematics. Technical Report.

[81] Kashefi, H. (2012). Mathematical Thinking in Multivariable Calculus through Blended Learning. Unpublished Ph.D. Thesis; Submitted to the Faculty of Education, Universiti Teknologi Malaysia.

[82] Stacey, K. (2006). What is Mathematical Thinking and Why 
is it Important. Progress Report of the APEC Project: Collaborative Studies on Innovations for Teaching and Learning Mathematics in Different Cultures (II), Lesson Study focusing on Mathematical Thinking.

[83] Hashemi, N., Abu, M. S., Kashefi, H. \& Mokhtar, M. (2015). Designing Learning Strategy to Improve Undergraduate
Students' Problem Solving in Derivatives and Integrals: A Conceptual Framework. Eurasia Journal of Mathematics, Science \& Technology Education; 11(2), 227-238.

[84] Roselainy, A. (2008). Changing My Own and My Students' Attitudes to Calculus through Working on Mathematical Thinking. Unpublished Ph. D. Thesis. Open University. UK. 